\begin{tabular}{|c|c|c|}
\hline & Int.J.Curr.Microbiol.App.Sci (2021) 10(08): 697-712 & \\
\hline & $\begin{array}{l}\text { International Journal of Current Microbiology and Applied Sciences } \\
\text { ISSN: 2319-7706 Volume } 10 \text { Number } 08 \text { (2021) } \\
\text { Journal homepage: http://www.ijcmas.com }\end{array}$ & 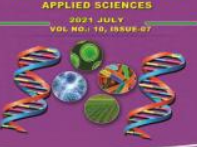 \\
\hline $\begin{array}{l}\text { EXCELLENT } \\
\text { PUBLISHERS }\end{array}$ & & www.ijcmas.com \\
\hline
\end{tabular}

Original Research Article

https://doi.org/10.20546/ijcmas.2021.1008.079

\title{
Isolation and Identification of Soil Mycoflora in Agricultural Fields of Hubli Taluk, Karnataka, India
}

\author{
Ch. Ramesh* and Mallesh Baradwad \\ Department of Botany, Karnatak University, Dharwad-580003, Karnataka, India \\ *Corresponding author
}

Key w or d s
Agricultural field,
Hubli Taluk,
Mycoflora, Soil
samples

Soil Mycoflora plays a significant role in soil quality, plant productivity and development of effective methods for studying the diversity, distribution, and behavior of microorganisms in soil environment is essential for a broader understanding of soil health. The soil samples were collected from agricultural fields of Arachis hypogaea L. Gossypium hirsutum L. and Zea mays L. in three different locations from Hubli Taluk, Karnataka, India. The fungi from these soil samples were isolated in March 2019 to March 2020. A total of 27 species belongs to 19 genera were isolated these includes two species of Ascomycetes, five species of Zygomycetes and remaining species were Mitosporic Fungi. None of basidiomycetes were isolated from these soils. The Mycoflora were isolated by using soil dilution method on Potato Dextrose agar medium supplemented with antibiotic Streptomycin. The different species belongs to various groups viz; Ascomycetes, Zygomycetes and Mitosporic Fungi were identified with the relevant literature and manuals of fungi. The dominant genera in all the agricultural fields were Aspergillus and Fusarium.

\section{Introduction}

Soil is a main component of the earth's ecosystem which comprises of organic matter, minerals, gases and large numbers of macro and microorganisms (Chandrashekar et al., 2014). A recent study on the diversity of soil fungi revealed around 80,500 operational taxonomic units (OTUs) occurring in soils worldwide (Tedersoo et al., 2014). Fungi are an important component of the soil Mycoflora typically constituting more of the soil biomass than bacteria, depending on soil depth and nutrient conditions (Ainsworth and Bisby, 1995).

Fungi are ubiquitous and important because of their presence in all climates and on all substrates. They can be easily cultured though some require special media to grow but the biotrophs fail to grow in axenic cultures. For proper growth and sporulation of a fungus 
specific requirements (nutrients, temperature, moisture, light, relative humidity etc) of a fungus are to be fulfilled (Ali et al., 2006).

The soil serves as a reservoir for many microbial communities of plants and herbs which can be producing Carbon dioxide and Nitrogen. The fungi play important role in soil ecosystem (Jadhav, et al., 2017). The aim of the present study is isolation and identification of fungal species from different agricultural fields of Hubli Taluk, Karnataka, India.

\section{Materials and Methods}

\section{Study Area}

Hubli is one of the taluk in Dharwad district of Karnataka, India. The study area lies on $15.21^{\circ}$ $\mathrm{N}$ latitude and $75.08^{\circ} \mathrm{E}$ longitude which has an average elevation of 640 meters. The temperature ranges from $15^{\circ} \mathrm{C}$ to $39^{\circ} \mathrm{C}$ and the annual rainfall is $838 \mathrm{~mm}$. The types of soil found in this taluk are black soil, deep black clay soil, red soil and deep red clay soils. Maize, Cotton, Groundnut, Sorghum, Pulses, Vegetables and oil seeds are the crops cultivated (Fig. I)

\section{Collection of Samples and isolation of fungi}

The soil samples in different agricultural fields of Sherewad, Belagali and Gabbur at Hubli taluk were collected in sterilized polythene bags and brought in to a laboratory for the isolation of soil fungi (Table-1). The soil fungi were isolated by Soil dilution method (Waksman, 1927), on Potato Dextrose Agar media. About $1 \mathrm{gm}$ of soil sample was suspended in $9 \mathrm{ml}$ of distilled water to make microbial suspensions $\left(10^{-1}\right.$ to $\left.10^{-4}\right)$. Dilution of $10^{-3}$ and $10^{-4}$ were used to isolate fungi. 1 $\mathrm{ml}$ of microbial suspension of each concentration was added to sterile Petri plates. Streptomycin was added to the medium before pouring into Petri plates for preventing bacterial growth. The Petri plates were incubated at $28^{\circ} \mathrm{C}$ for a period of 4-7 days. During incubation plates were observed regularly and fungal growth were noted. After 7 days of incubation, photographs of plates were taken. The colony forming units (CFU) of the fungal isolates were calculated. Isolated fungal colonies were used for preparation of slides. Slides were prepared by using cotton blue stain and lactophenol as mounting medium. Slides were observed under the light microscope and photo micrography of fungi was also taken.

\section{Identification of Fungi}

Colony colour and morphological characters were also observed besides hyphal structure, spore size, shapes and spore bearing structures. Fungi were identified by using standard protocols and manuals of fungi (Gilman, 1957, Nagamani, Kunwar and Manoharachary 2006, Subramanian 1971, Barnett 1955 and Ainsworth 1965). All the results were calculated and statistically analysed.

\section{Statistical analysis}

The number of colonies per plate in $1 \mathrm{~g}$ of soil was calculated. The percentage of contribution of each isolate was calculated by using the following formula

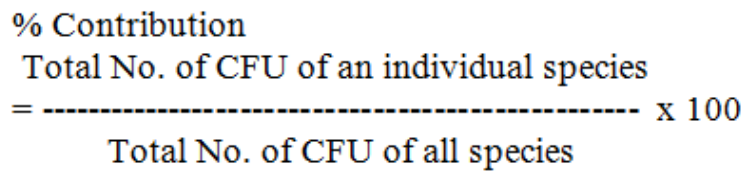

*CFU-Colony Forming Unit

\section{Results and Discussion}

The present study reveals a total of 27 fungal species were identified by different soil samples from Agricultural fields of Hubli 
taluk. The maximum fungal species belonging to Mitosporic Fungi (20 Species), Zygomycetes (05 Species) and Ascomycetes (02 speices) were observed. Among these 04 species of Aspergillus, 04 species of Fusarium, 02 Species of Alternaria, 02 species of Rhizopus, and one species of Mucor, Cheatomium, Acremonium, Curvularia, Emericella, Penicillium, Paecilomyces, Pestalotiopsis, Bipolaris, Drechslera, Nigrospora, Humicola, Cladosporium, Cunninghmella, Absidia, were observed (Table-2).

The percentage occurrence of Mitosporic Fungi were maximum i.e. $78.15 \%$ followed by Zygomycetes $16.80 \%$ and Ascomycetes 05.04\%. Aspergillus, Fusarium, Alternaria, Rhizopus, Mucor, Curvularia, Penicillium, Acremonium, Bipolaris and Cladosporium were found frequently during the study on the other hand Humicola, Emericella, Chaetomium, Drechslera, Paecilomyces, Pestalotiopsis and Nigrospora were found occasionally.

Soil Mycoflora plays a significant role in soil biogeochemical processes which determine plant productivity. Successful functioning of introduced microbial bioinoculants and their influence on soil health. Complete efforts have been made to investigate soil microbial diversity and their distribution in soil habitat (Madhavan et al., 2012). The soil mycoflora in different crops like Arachis hypogaea L. Gossypium hisutum L. and Zea mays L. were observed. The most common among them like Absidia corymbifera (3.36\%), Cunninghamella elegans (0.84\%), Mucor racemosus (5.04\%), Rhizopus oryzae (4.62\%), Rhizopus stolonifer (2.94\%), Chaetomium indicum (0.84\%), Acremonium inflatum (4.02\%), Alternaria alternate (7.98\%), Alternaria solani (3.78\%), Asperillus flavus
(5.88\%), Aspegillus fumigates(5.46\%), Aspegillus nidulans (5.88\%), Aspegillus Niger (6.30\%), Bipolaris tetramera (2.10\%), Cladosporium elatum (3.36\%), Curvularia lunata (7.14\%), Drechslera graminea (2.10\%), Emericella nidulans (4.20\%), Fusarium moniliforme (3.78\%), Fusarium oxysporum (4.62\%), Fusarium solani (3.78\%), Fusarium incarnatum (2.94\%), Humicola fuscoatra (1.26\%), Nigrospora sphaerica (0.84\%), Paecilomyces variotii (2.10\%), Penicillium rubrum (2.10\%), Pestalotiopsis microspora (2.10\%) (Table 3). Diversity of fungi found to be higher in agricultural field of Zea mays L as compared to Gossypium hirsutum L and Arachis hypogeal L. highest fungal population was observed because of high soil moisture. Among the isolates Aspergillus and Fusarium were dominant in all the agricultural soil of all the areas mentioned due to high sporulation and production of different types of toxins from Aspergillus and Fusarium species may prevent the growth of other fungal species. The percentage contribution of each fungal species in different crop plants was statistically analyzed (Figure 2 to Figure 5).

A gram of garden soil can contain around 1 million fungal species such as yeasts and molds. The fungi do not have chlorophyll and are not able to photosynthesis. They do not use atmospheric carbon dioxide as a source of carbon, therefore they are chemo heterotrophic meaning that, like animals they require a chemical source of energy rather than being able to use light as an energy source as well as organic substrates to get carbon for growth and development. Many fungi are parasitic, frequently causing diseases to their living host plant but some have beneficial relationship with plants. Where ever adequate moisture, temperature and organic substrates are obtained there fungi are present. 
Table.1 Soil samples collected from different locations of Hubli Taluk.

\begin{tabular}{|c|c|c|}
\hline Sample No & Sampling Location & Types of Crops \\
\hline 1. & Sherewad & Arachis hypogaea L. \\
\hline 2. & Gabbur & Gossypium hirsutum L. \\
\hline 3. & Belagali & Zea mays L. \\
\hline
\end{tabular}

Table.2 Occurrence of Fungal species in Different crop fields in Hubli Taluk.

\begin{tabular}{|c|c|c|c|c|}
\hline \multirow[t]{2}{*}{ Sl. No } & \multirow{2}{*}{$\begin{array}{c}\text { Mycoflora } \\
\text { Zygomycetes }\end{array}$} & \multicolumn{3}{|c|}{ Agricultural Fields } \\
\hline & & $\begin{array}{c}\text { Arachis } \\
\text { hypogaea } \mathrm{L} .\end{array}$ & $\begin{array}{l}\text { Gossypium } \\
\text { hirsutum L. }\end{array}$ & Zea mays $\mathrm{L}$. \\
\hline 1. & Absidia corymbifera. (Cohn) Sacc. \& Trotter & + & + & - \\
\hline 2. & Cunninghamella elegans. Lendner & - & + & - \\
\hline 3. & Mucor racemosus. Bull & + & + & + \\
\hline 4. & Rhizopus oryzae. Went et Gerlings & + & - & + \\
\hline \multirow[t]{2}{*}{5.} & Rhizopus stolonifer. Vuillemin & + & + & - \\
\hline & Ascomycetes & & & \\
\hline 6. & Chaetomium indicum Corda. & - & + & - \\
\hline \multirow[t]{2}{*}{7.} & Emericella nidulans. Vuill. & + & - & + \\
\hline & Mitosporic Fungi & & & \\
\hline 8. & Acremonium inflatum (Dickinson)W Gams. & - & + & + \\
\hline 9. & Aspergillus flavus Link. & + & + & + \\
\hline 10. & Aspergillus fumigatus Fresenius. & + & + & + \\
\hline 11. & Aspergillus nidulans G Winter. & + & + & + \\
\hline 12. & Aspergillus niger Van Tieghem. & + & + & + \\
\hline 13. & Alternaria alternate (Fr.) Keissl. & + & + & + \\
\hline 14. & Alternaria solani Sorauer. & + & + & + \\
\hline 15. & Bipolaris tetramera Shoemaker & + & - & + \\
\hline 16. & Cladosporium elatum (Harz) Nannf. & + & + & + \\
\hline 17. & Curvularia lunata Boedijn. & + & + & + \\
\hline 18. & Drechslera graminea Rabenh. ex Schltdl. & - & + & + \\
\hline 19. & Fusarium moniliforme J. Sheld. & + & + & + \\
\hline 20. & $\begin{array}{l}\text { Fusarium oxysporum Schlecht. emend. } \\
\text { Snyder \& Hansen }\end{array}$ & + & + & + \\
\hline 21. & Fusarium solani (Mart.) Sacc. & + & + & + \\
\hline 22. & Fusarium incarnatum Desm. & + & + & + \\
\hline 23. & Humicola fuscoatra Traaen. & + & - & + \\
\hline 24. & Nigrospora sphaerica Mason. & - & - & + \\
\hline 25. & Paecilomyces variotii Bainier & - & + & - \\
\hline 26. & Penicillium rubrum Stoll. & - & + & + \\
\hline \multirow[t]{2}{*}{27.} & Pestalotiopsis microspora Speg. & + & + & - \\
\hline & Total & 20 & 22 & 21 \\
\hline
\end{tabular}

'+ ' indicates Presence of species

' - 'indicates Absence of species 
Table.3 Percentage contribution of fungal species in different crop fields of Hubli taluk.

\begin{tabular}{|c|c|c|c|c|}
\hline \multirow{2}{*}{$\begin{array}{l}\text { Sl. } \\
\text { No }\end{array}$} & \multirow[t]{2}{*}{ Mycoflora } & \multicolumn{3}{|c|}{ Percentage contribution } \\
\hline & & $\begin{array}{c}\text { Arachis } \\
\text { hypogaea } \mathrm{L} .\end{array}$ & $\begin{array}{c}\text { Gossypium } \\
\text { hirsutum L. }\end{array}$ & Zea mays $\mathrm{L}$. \\
\hline 1. & $\begin{array}{c}\text { Absidia corymbifera. (Cohn) Sacc. \& } \\
\text { Trotter }\end{array}$ & 5.63 & 3.89 & 00 \\
\hline 2. & Cunninghamella elegans. Lendner & 00 & 2.5 & 00 \\
\hline 3. & Mucor racemosus. Bull & 7.04 & 3.89 & 4.44 \\
\hline 4. & Rhizopus oryzae. Went et Gerlings & 7.04 & 00 & 6.66 \\
\hline 5. & Rhizopus stolonifer. Vuillemin & 5.63 & 3.89 & 00 \\
\hline 6. & Chaetomium indicum Corda. & 00 & 2.59 & 00 \\
\hline 7. & Emericella nidulans. Vuill. & 7.04 & 00 & 5.55 \\
\hline 8. & $\begin{array}{c}\text { Acremonium inflatum (Dickinson) W } \\
\text { Gams. }\end{array}$ & 00 & 5.19 & 6.66 \\
\hline 9. & Aspergillus flavus Link. & 8.45 & 3.89 & 5.55 \\
\hline 10. & Aspergillus fumigatus Fresenius. & 2.81 & 6.49 & 6.66 \\
\hline 11. & Aspergillus nidulans G Winter. & 8.45 & 2.59 & 7.77 \\
\hline 12. & Aspergillus niger Van Tieghem. & 7.04 & 7.79 & 4.44 \\
\hline 13. & Alternaria alternate (Fr.) Keissl. & 7.04 & 7.79 & 8.88 \\
\hline 14. & Alternaria solani Sorauer. & 2.81 & 5.19 & 3.33 \\
\hline 15. & Bipolaris tetramera Shoemaker & 2.81 & 00 & 3.33 \\
\hline 16. & Cladosporium elatum (Harz) Nannf. & 2.81 & 5.19 & 2.22 \\
\hline 17. & Curvularia lunata Boedijn. & 8.45 & 6.49 & 7.77 \\
\hline 18. & $\begin{array}{c}\text { Drechslera graminea Rabenh. ex } \\
\text { Schltdl. }\end{array}$ & 00 & 5.19 & 1.11 \\
\hline 19. & Fusarium moniliforme J. Sheld. & 2.81 & 5.19 & 3.33 \\
\hline 20. & $\begin{array}{c}\text { Fusarium oxysporum Schlecht. emend. } \\
\text { Snyder \& Hansen }\end{array}$ & 2.81 & 3.89 & 6.66 \\
\hline 21. & Fusarium solani (Mart.) Sacc. & 4.22 & 2.59 & 4.44 \\
\hline 22. & Fusarium incarnatum Desm. & 1.40 & 3.89 & 3.33 \\
\hline 23. & Humicola fuscoatra Traaen. & 2.81 & 00 & 1.11 \\
\hline 24. & Nigrospora sphaerica Mason. & 00 & 00 & 2.22 \\
\hline 25. & Paecilomyces variotii Bainier & 00 & 5.19 & 1.11 \\
\hline 26. & Penicillium rubrum Stoll. & 00 & 2.59 & 3.33 \\
\hline 27. & Pestalotiopsis microspora Speg. & 2.81 & 3.89 & 00 \\
\hline
\end{tabular}


Fig.1 Location map of study area.

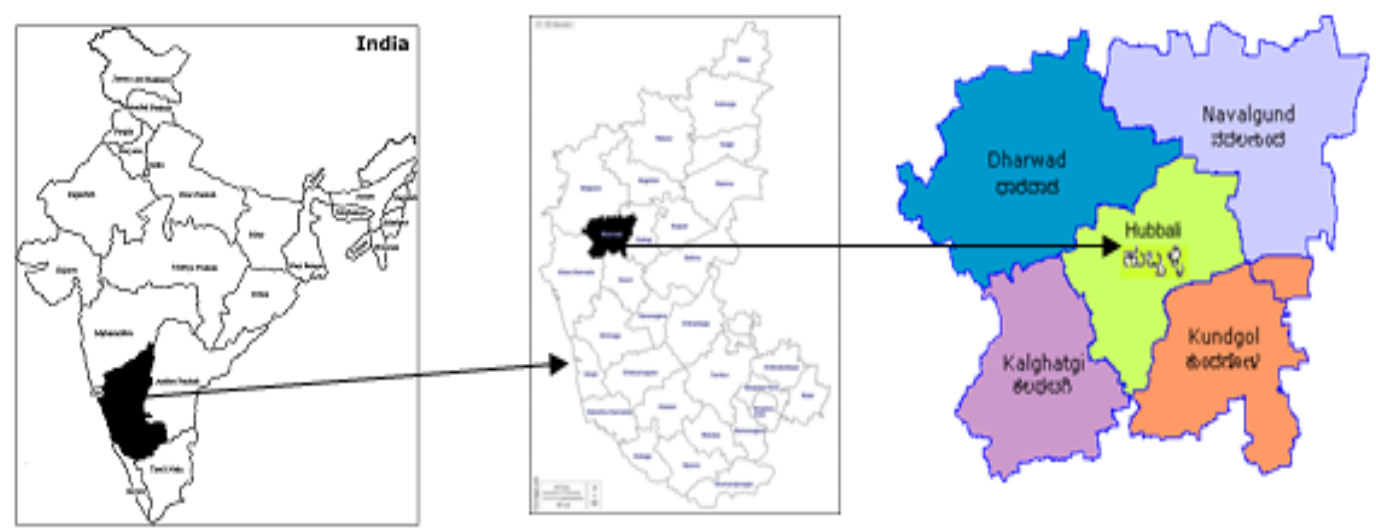

Fig.2 Frequency of Occurrence of Mycoflora in three crop fields from Hubli Taluk (Maize, Cotton and Ground nut)

Frequency of occurrence of mycoflora in three crop fields from Hubli Taluk

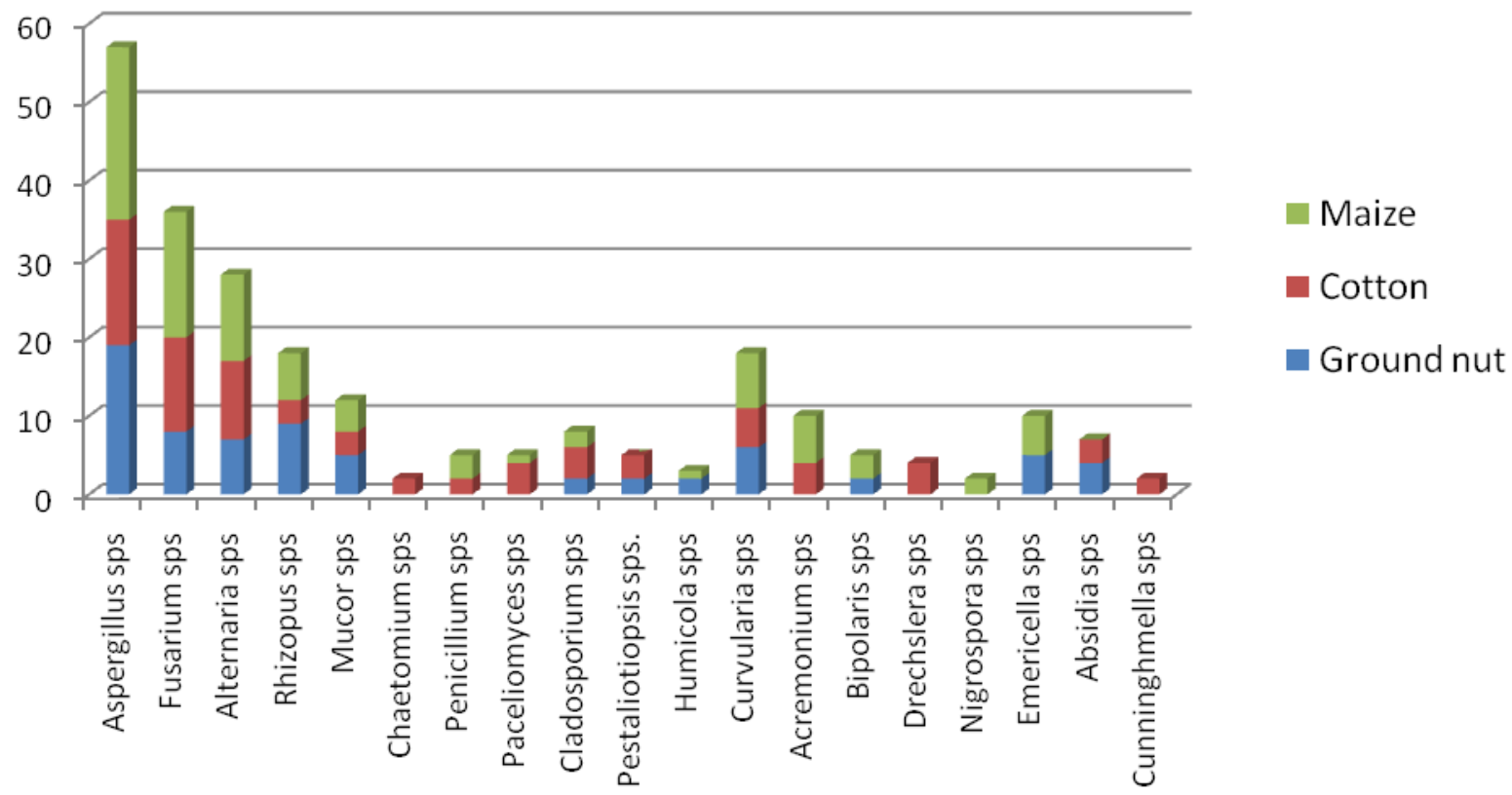

Mycoflora 
Fig.3 Percentage contribution of Mycoflora in Gossypium hirsutum L. of Hubli Taluk.

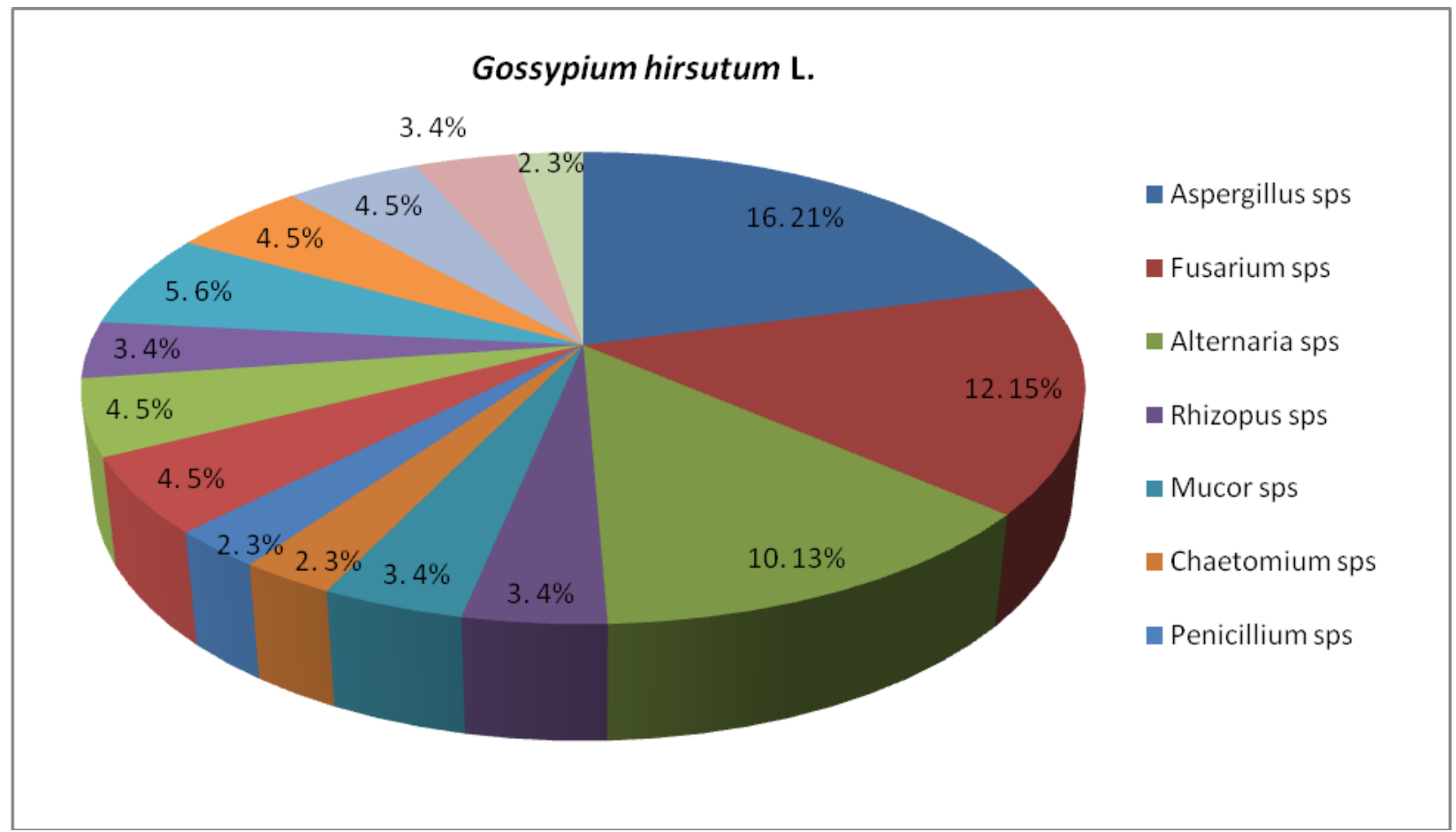

Fig.4 Percentage contribution of Mycoflora in Arachis hypogaea L. of Hubli Taluk.

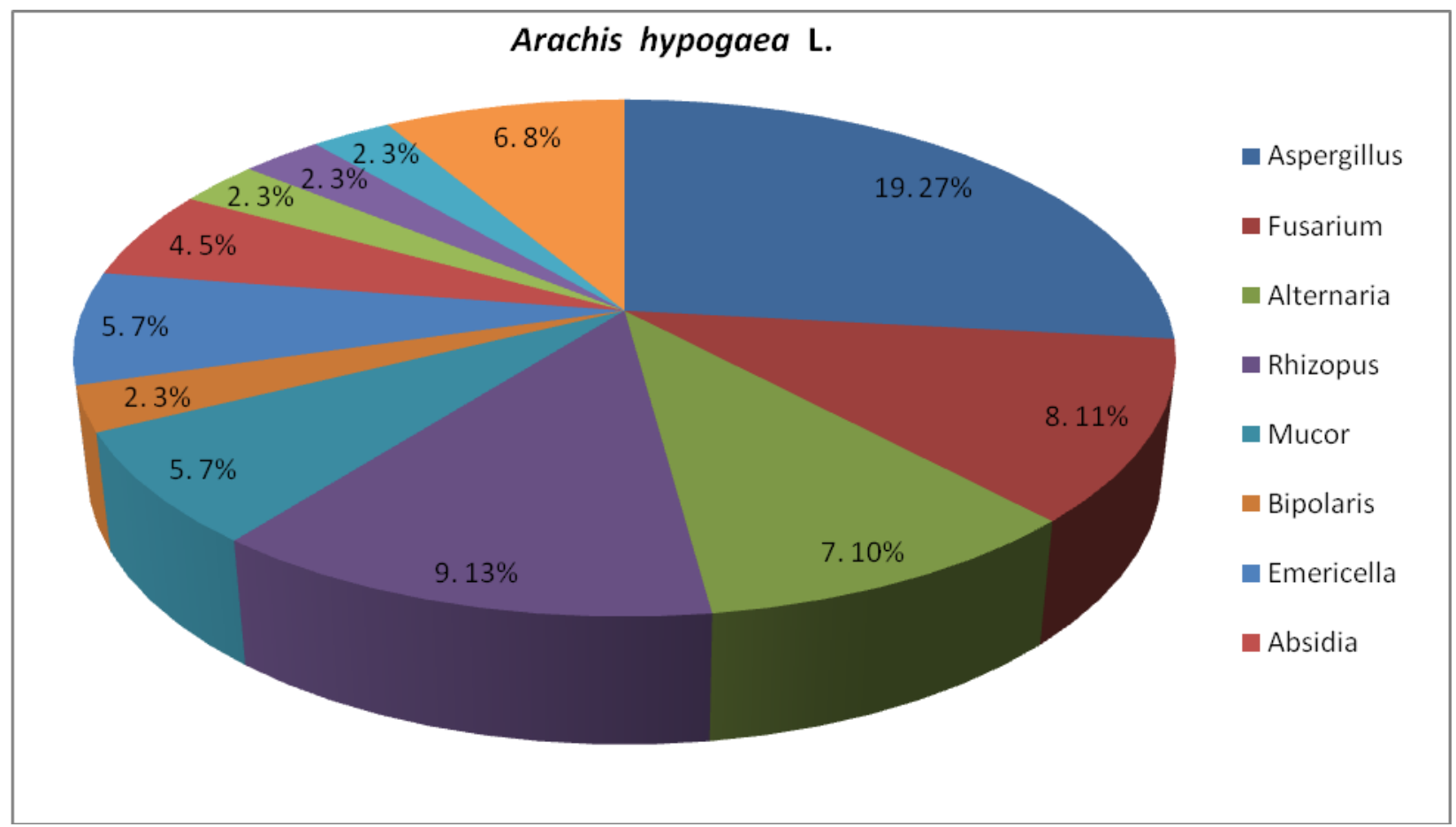


Fig.5 Percentage contribution of Mycoflora in Zea mays L. of Hubli Taluk.

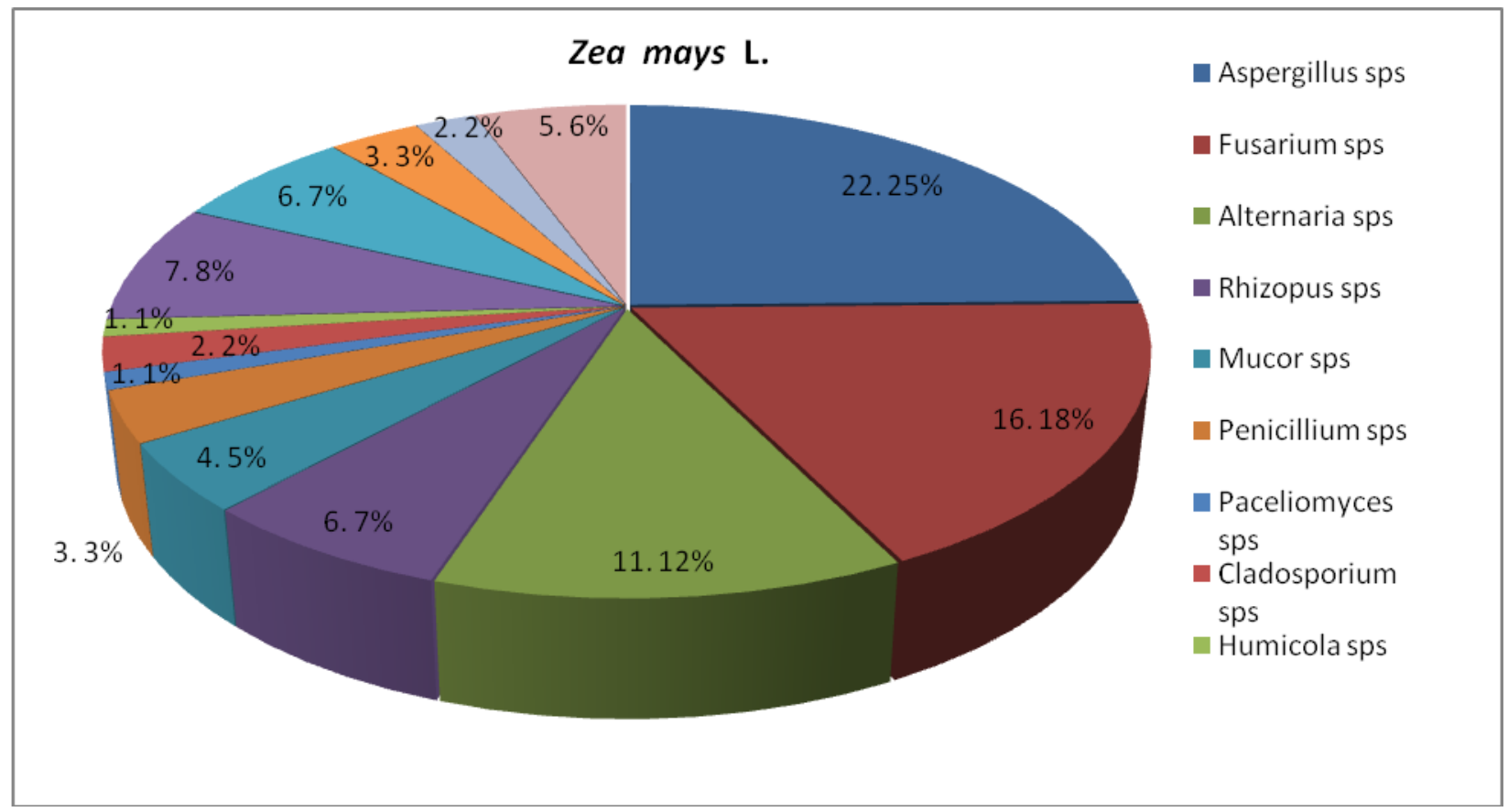

\section{Photo Plate.I}

1. Absidia corymbifera

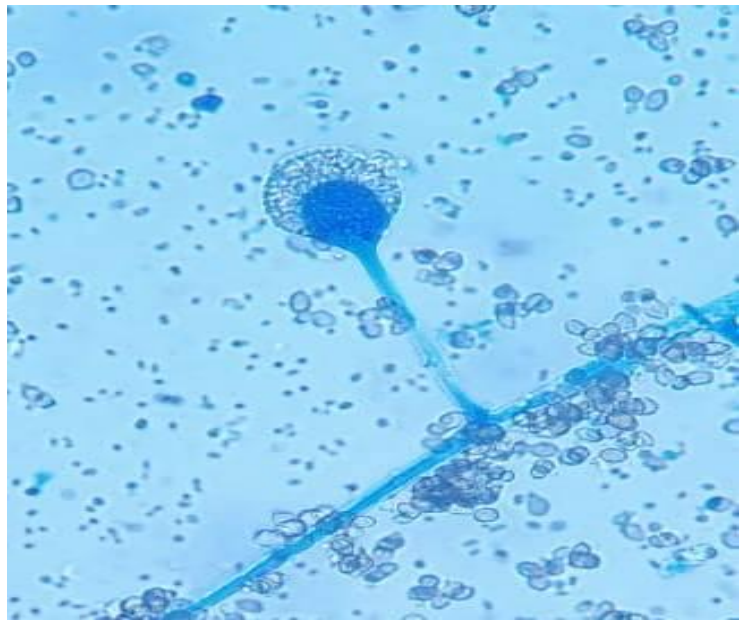

2. Cunninghamella elegans

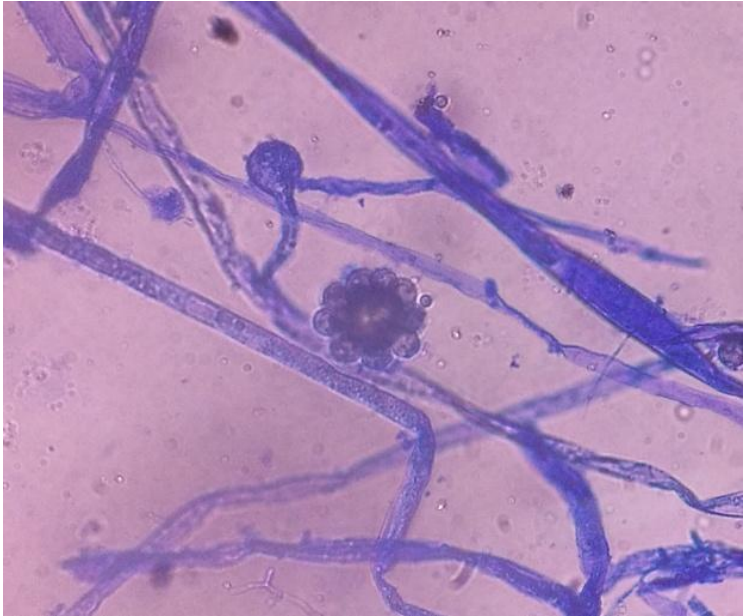




\section{Mucor recemosus}

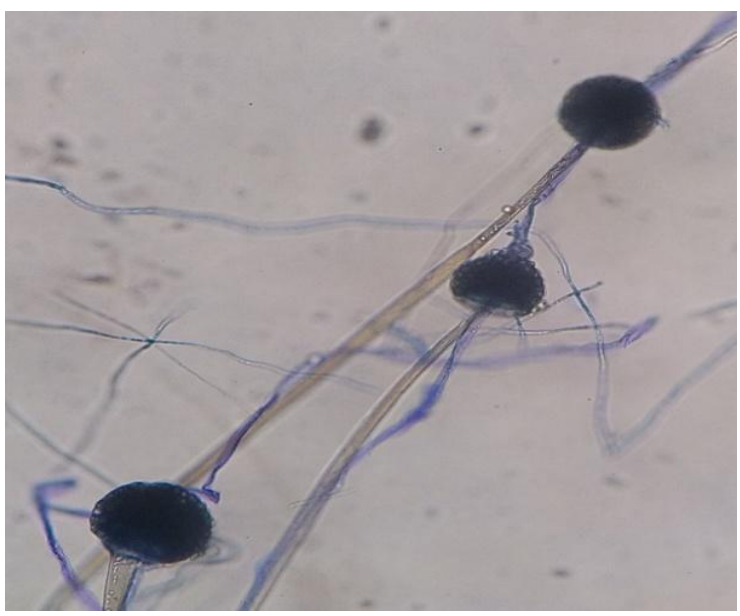

5. Rhizopus stolonifer

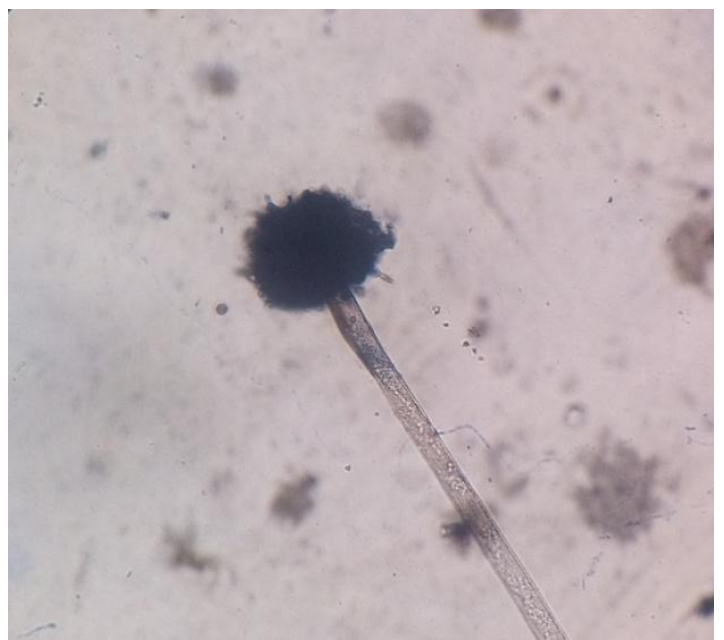

\section{Rhizopus oryzae}

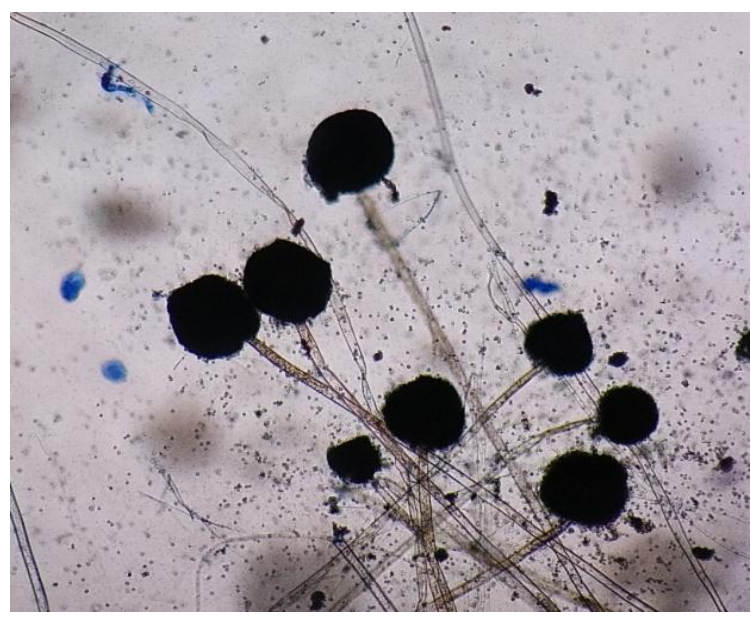

6. Chaetomium indicum

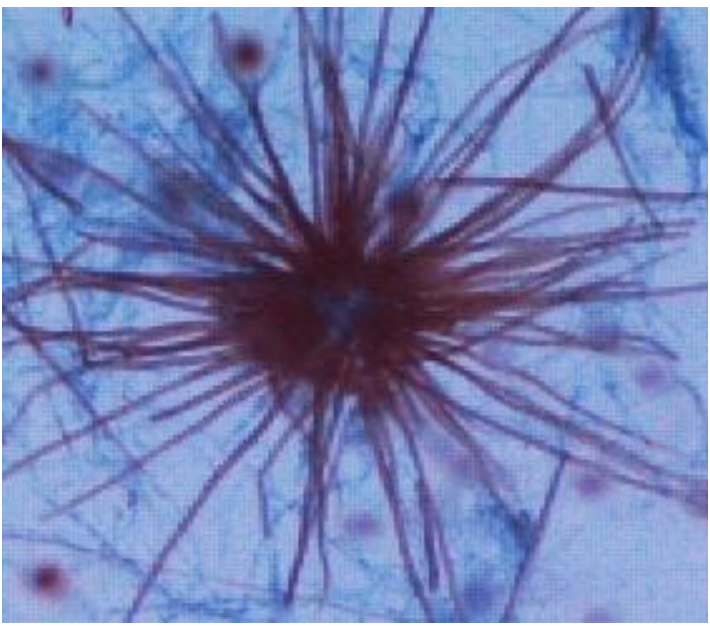




\section{Photo Plate.II}

7. Emericella nidulans

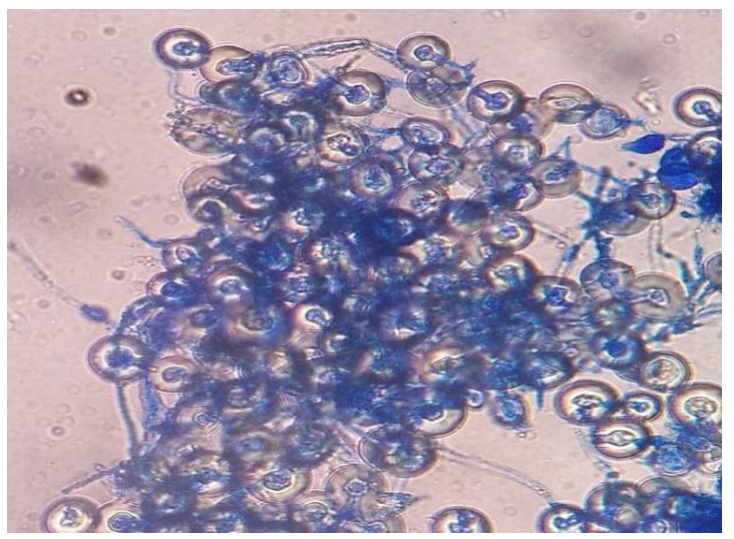

9. Alternaria alternata

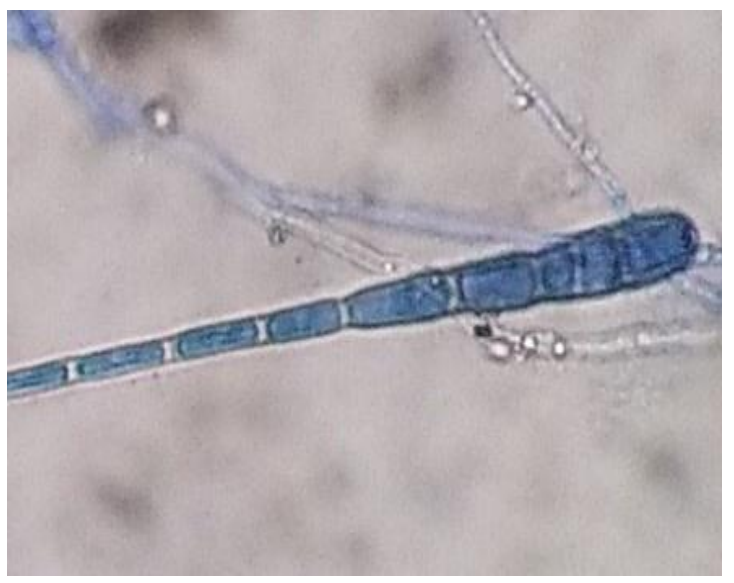

11. Aspergillus flavus

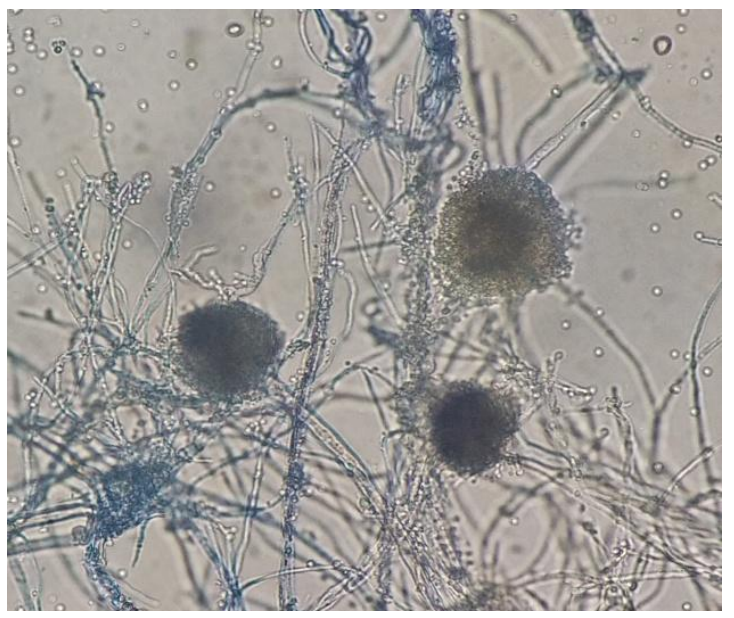

8. Acremonium inflatum

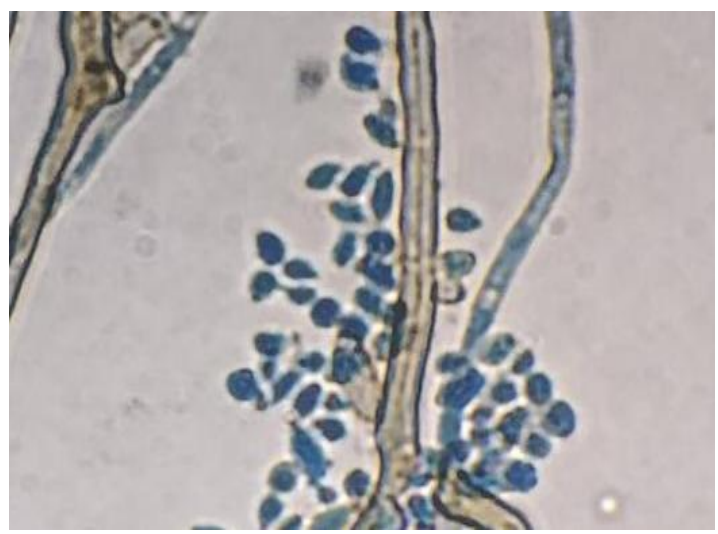

10. Alternaria solani

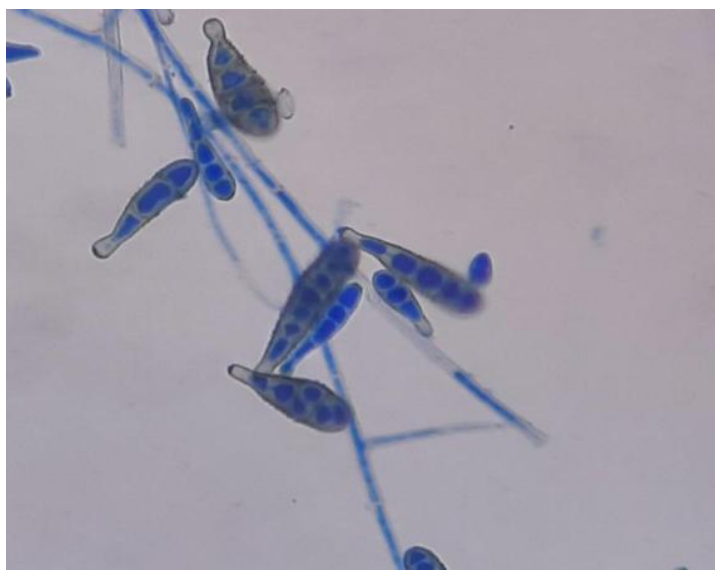

12. Aspergillus fumigatus

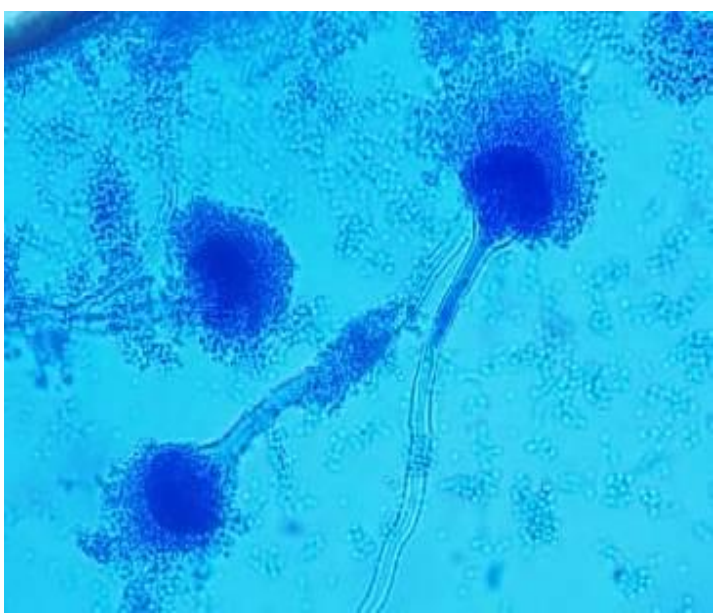




\section{Photo Plate.III}

13. Aspergillus nidulans

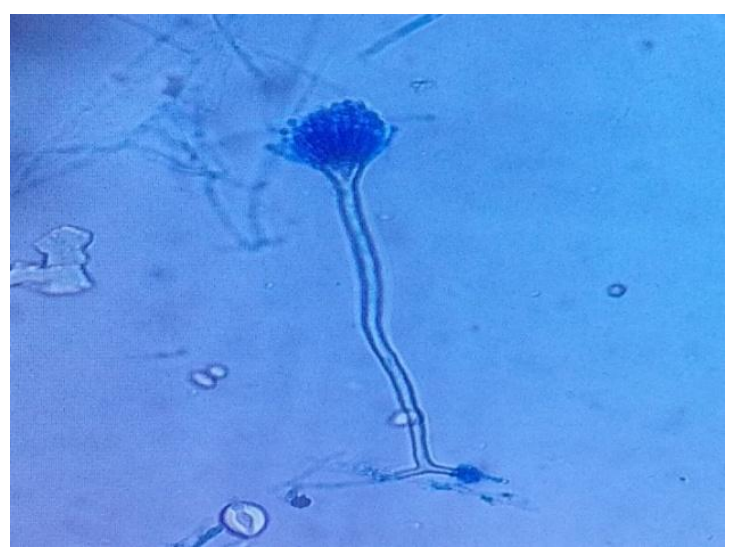

15. Bipolaris spicifera

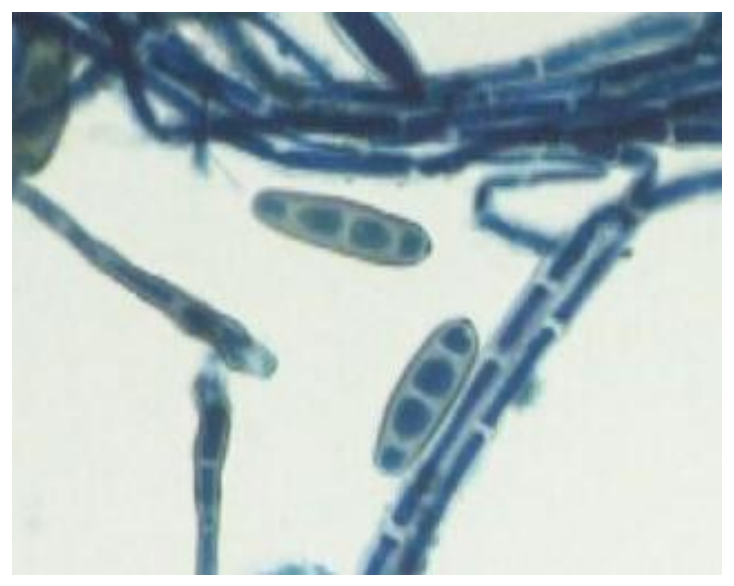

17. Curvulari lunata

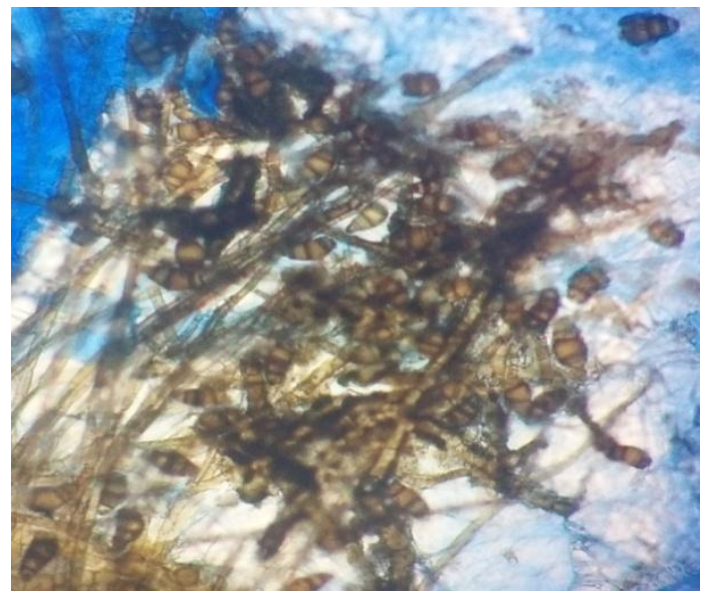

14. Aspergillus niger

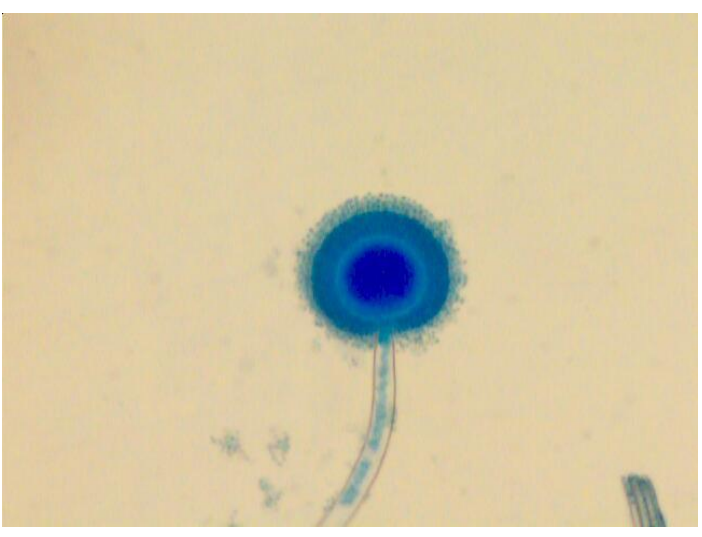

16. Cladosporium elatum

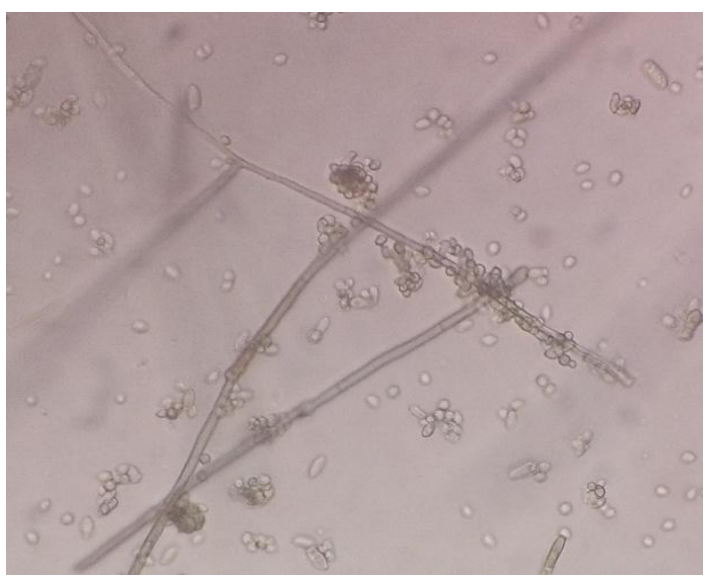

18. Drechslera graminea

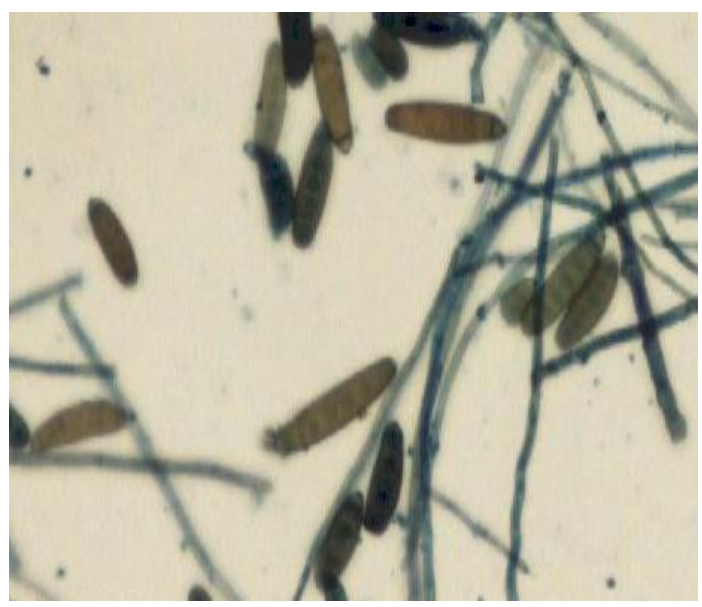




\section{Photo Plate.IV}

19. Fusarium moniliforme

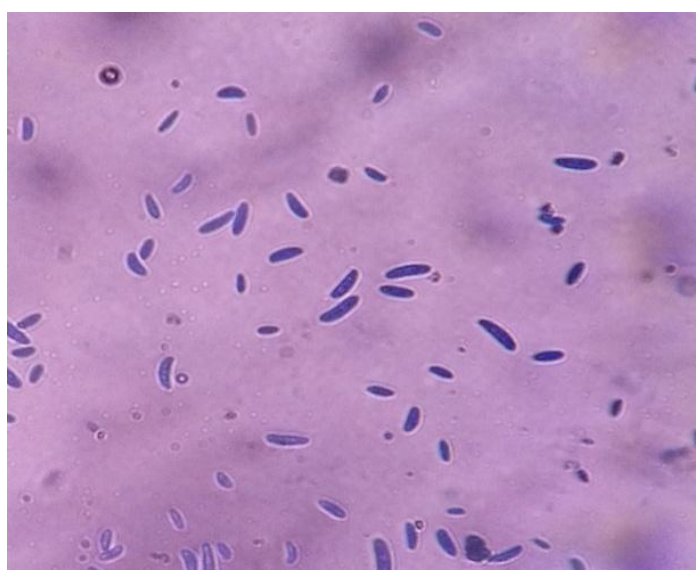

21. Fusarium solani

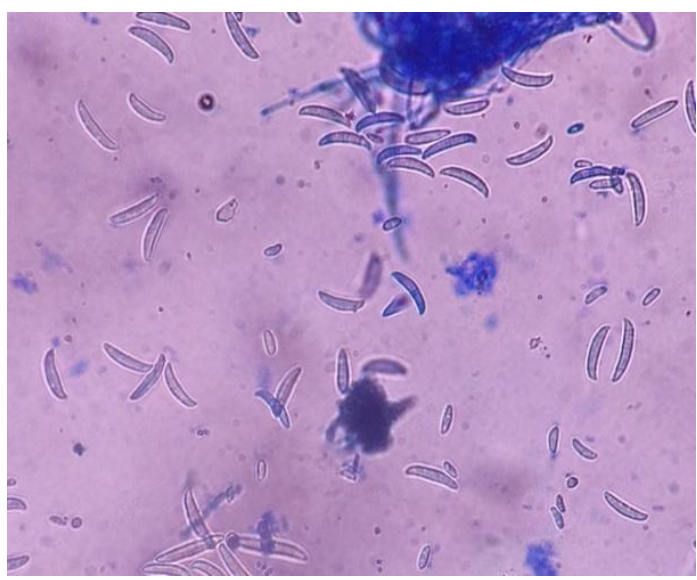

23. Humicola fascoatra

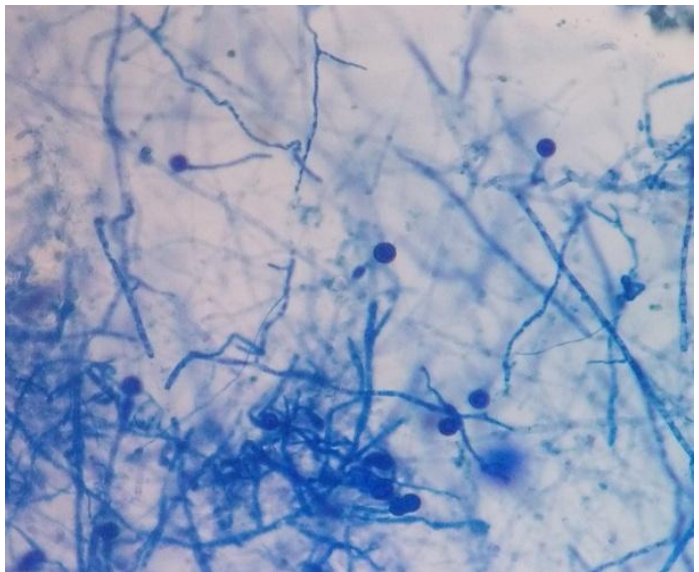

20. Fusarium oxysporum

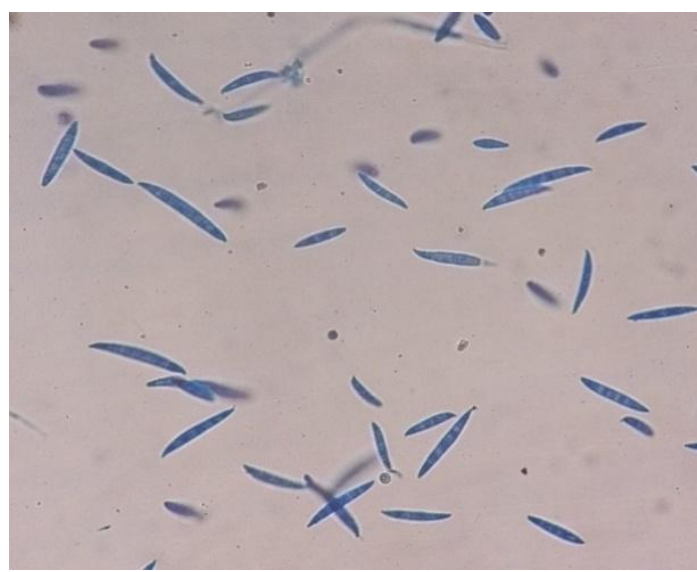

22. Fusarium incarnatum

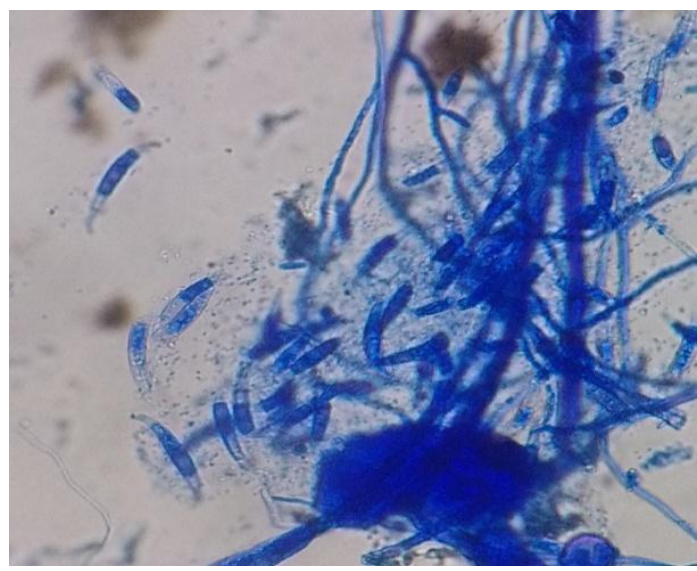

24. Nigrospora sphaerica

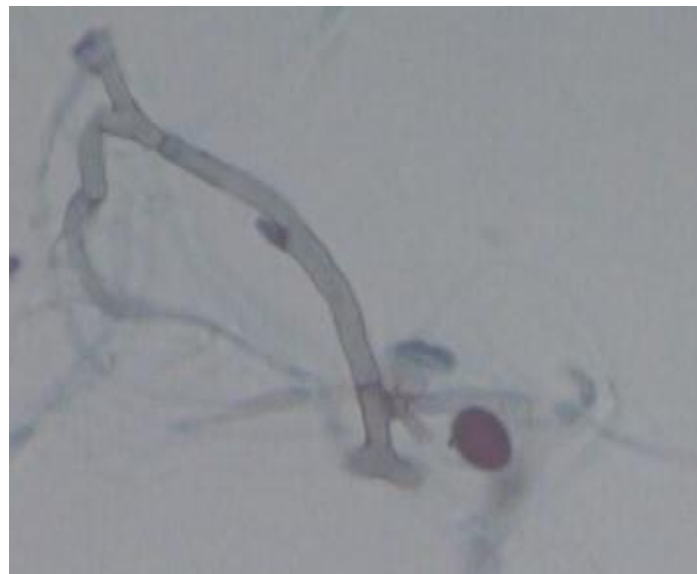


Photo Plate.V

25. Paecilomyces variotii

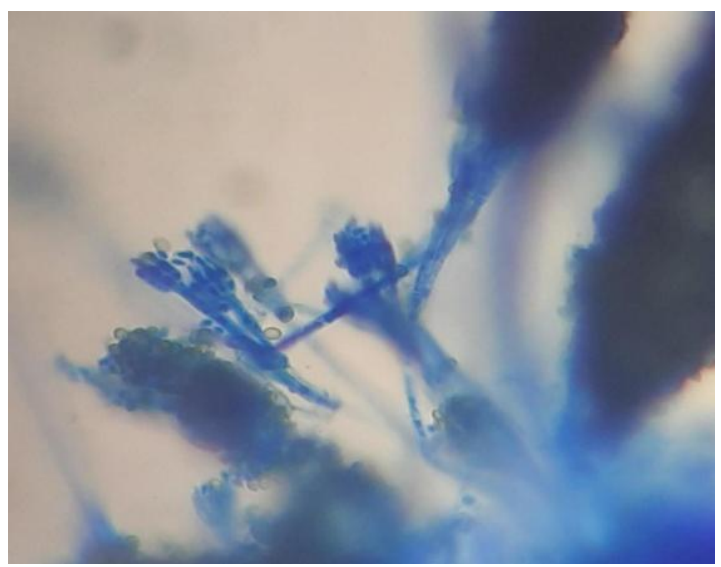

26. Penicillium rubrum

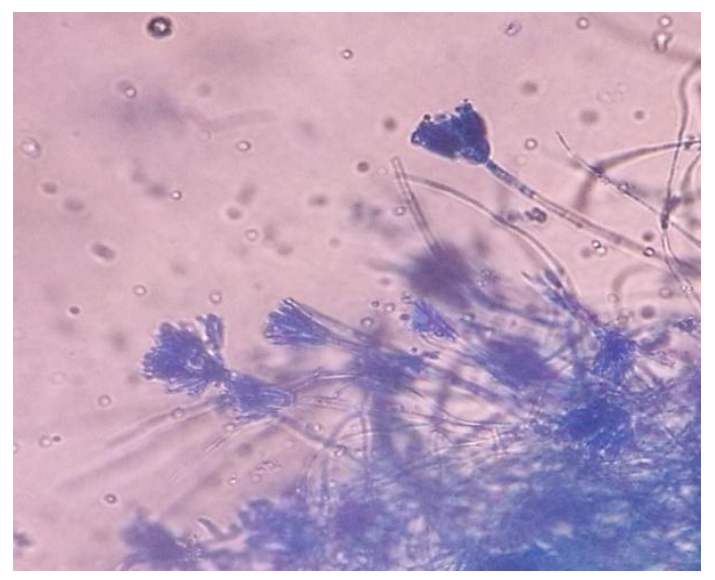

27. Pestalotiopsis microspora

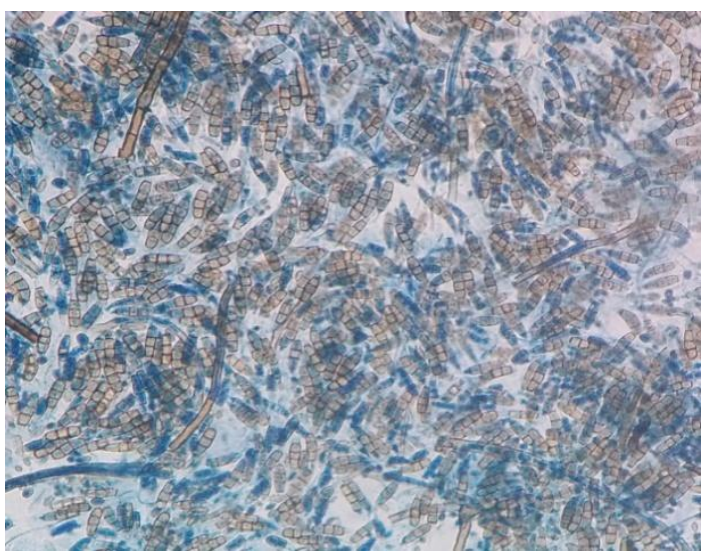


Diversity of fungi tends to increase in tropical regions, but detailed studies are only in their infancy (Issac et al., 1993) from the mycelia. The fungi is able to throw its fruiting, the visible part above the soils (e.g. Mushrooms, toad stools, puffballs), which may contain millions of spore.

The present study reveals that, the Mitosporic Fungi frequently found in soil because of their rapid growth rate of asexual reproduction, as they causes various diseases to crop plants and their rich flora in air and soil.

Mycoflora of agricultural soils is affected by various physico-chemical properties. Organic content, moisture and $\mathrm{pH}$ of soil have major impact on fungal diversity of a soil (Gaddeyya et al., 2012). The diversity of fungi in soil is mainly affected positively as well as negatively on growth of crop plants (Ratna Kumar et al., 2015).

Our findings are in accordance with the results of Ratna Kumar et al., (2019) studied Soil Mycoflora in different soil samples in crop fields of Chintalapudi Mandal in West Godavari District, Andhra Pradesh, India. They were isolated genera like Aspergillus, Mucor, Curvularia, Fusarium, Penicillium and Rhizopus. Similar genera were isolated during our investigation.

Jadhav et al., (2017) they have isolated 18 species belongs to 4 genera from Kadegaon Tehsil, Sangli District, Maharashtra, India. The Aspergillus genera were dominant. Similar results were reported during our investigation.

In our investigation among the obtained fungal isolates 27 species belongs to 19 genera in that Aspergillus and Fusarium species were dominant, similar work has been done by Gnanasekaran et al., (2015) about sixty five fungal species representing 26 genera were isolated and identified of Soil Mycoflora in Banana Field at Manachanallur, Tiruchirappalli District., Tamil Nadu and found Aspergillus, Penicillium and Trichoderma species were dominant in their study.

Ratna kumar et al., (2015), about 18 species belongs to 6 genera were isolated and identified from Soil Mycoflora in agricultural fields of Tekkali Mandal in Srikakulam District, Andhra Pradesh and found that genera Aspergillus and Penicillium were dominant in their study. In current study we have isolated a total of 27 fungal species belongs to 19 genera isolated and the dominant genera in all the agricultural fields were Aspergillus and Fusarium species.

Chandrashekar et al., (2014), isolated and identified Fungal diversity in rhizospheric soils from paddy, pulses, ragi, sugarcane, vegetables and banana fields of Nanjangud taluk of Mysore district, Karnataka, and recorded 10 fungal species representing 7 genera. They have reported Aspergillus, Alternaria, Mucor, Curvularia, Fusarium, Penicillium and Rhizopus. We have isolated 27 species belongs to 19 genera in that Aspergillus and Fusarium and Alternaria were dominant.

Shiny et al., (2013), Investigated Mycoflora of total of 12 species belongs to 6 genera from Soil in Different Crop Fields at Narasannapeta Mandal, Srikakulam District. Aspergillus and Penicillium were dominant in their study. In our investigation total of 27 fungal species belongs to 19 genera isolated and the dominant genera in all the crops were Aspergillus and Fusarium species.

The soil samples were collected from the month of March 2019 to March 2020 in an agricultural field of Arachis hypogaea L. Zea mays L. and Gossypium hirsutum L. in three 
different locations from Hubli Taluk, Karnataka, India. In the present study, the isolated fungi were identified on the basis on colony colour, hyphal structure, spore size, shapes and spore bearing structures. It is known that Potato Dextrose Agar media, is the general media most widely used in the isolation of fungi, having a complete nutritional basis (Agrios, 1988), this is probably the reason why colony development was faster with respect to other media. Earlier work reported that maximum growth of fungi, Potato Dextrose Agar Media was most favorable (Maheshwari, 2000). In the present study I also used Potato Dextrose Agar medium for the isolation of the fungi, the growth of the fungus was maximum. Fungal population dominate the soil food web (although they are less in number than the bacteria). Fungi have $40-55 \%$ carbon use efficiency so they store and recycle more carbon $(\mathrm{C})$ compared to bacteria.

\section{Acknowledgement}

Authors are thankful to Chairman, P. G Department of Botany, Karnatak University, Dharwad, for providing necessary Laboratory Facilities for conducting this study and Karnatak University, Dharwad, India for providing financial assistance in the form of URS (University Research Studentship) to the second author.

\section{References}

Agrios, G., 1988. Plant Pathol., $3^{\text {rd }}$ ed. In: Noriega Group, editor Mexico: Academic Press, p. 803.

Ainsworth, G. C., Bisby, G. R., 1995. Dictionary of the Fungi. $8^{\text {th }}$ ed. CABI: 445

Ali, A., Nosheen Akhtar., J. H. Mirza., and Rukhsana Bajwa. 2006. Addition to micromycetes of Lahore, Pakistan. Mycopathohgy, 4(2):17-25.
Barnett, H. L., 1955. Illustrated genera of imperfect fungi, $2^{\text {nd }}$ ed. Burgers Publishing company U S A.

Chandrashekar, M. A., Soumya Pai, K. And Raju, N. S., 2014. Fungal diversity of rhizosphere soils in different agricultural fields of Nanjangud Taluk of Mysore District, Karnataka, India. Int. J. Curr. Microbiol. App. Sci., 3(5): 559-566.

Gaddeyya, G., Shiny Niharika, P., Bharathi, P., and Ratna Kumar P. K., 2012. Isolation and identification of soil mycoflora in different crop fields at Salur Mandal. Adv. Appl. Sci. Res., 3(4):2020-2026.

Gilman, J. C., 2001. A Manual of Soil fungi, $2^{\text {nd }}$ Indian edition, Biotech Books, Delhi.

Gnanasekaran, P., Mohamed. S., and Panneerselvam. A., 2015. Isolation and Identification of Soil Mycoflora in Banana Field at Manachanallur, Tiruchirappalli District, Tamil nadu. Int. J. Curr. Microbiol. App. Sci., 4(7): 729-740.

Isaac, S. J. C., Frankland, R. Watling, and Whalley A. J. S., 1993. Aspects of Tropical Mycology, Cambridge University Press, Cambridge, U.K.

Jadhav, Shilpa. Y., Shinde, Pratiksha. P., 2017. Isolation and Identification of Soil Fungi from Kadegaon Tehsil, Sangli District, Maharashtra, India. Int. J. Scient. Res. Publ., 7(12): 616-620.

Madhavan, S., Kulothungan, S., Panneerselvam, A., Karnan, M., and Senthilkumar, G., 2012. Effect of biofertilizers on morphological and physiological parameters of cow pea (Vigna unguiculata). Adv. in Appl. Sci. Res., 3(5):3269-3272.

Maheshwari, R., Bhardwaj, G. and Bhat, M. K., 2000. Thermophilic fungi: Their physiology and enzymes, Microbiology Mol. Biol. Rev., 63: 461- 
488.

Nagamani, A., Kumar, I. K., and Manoharachary, C., 2006. Hand Book of Soil Fungi, I.K. International Publishing House Pvt. Ltd, New Delhi, India.

Ratna Kumar, P. K., Hemanth, G., Niharika, P. S., and Kolli, S. K., 2015. Isolation and Identification of Soil Mycoflora in Agricultural Fields at Tekkali Mandal in Srikakulam District. Int. J. Adv. in Pharm. Biol and Chem., 4: 484-490.

Ratna Kumar, P. K, Manimala, N., and Samuel, K. K., 2019. Isolation and Identification of soil Mycoflora in Crop Fields at Chintalapudi Mandal, West Godavari District. Int. J. of Innov. Res. in Sci. Eng. and Tech., 8 (3): 2695-2700.

Sandhya, S., Vivek, K., Prasad, B., Anuradha, B., Sourabh, C., Sujit, W., and Kanade, M. B., 2019. Isolation and
Identification of Soil Fungi of Banana Fields form Baramati Area of Pune District of Maharashtra, India. Int. J. Curr. Microbiol. App. Sci., 8(7):21932197.

Shiny, N. P., Gaddeyya, G., and Ratna Kumar, P. K., 2013. An Investigation on Soil Mycoflora of Different Crop Fields at Narasannapeta Mandal, Srikakulam District. Int. Res. J. of Env. Sci., 2(9): 38-44.

Subramanian, C. V., 1971. Hypomycetes- An account of Indian species, Indian Counc. Agri. Res., New Delhi.

Tedersoo, L., Bahram, M., Polme, S., Koljalg, U., Nourou, S. Y., Ravi, W., 2014. Global diversity and geography of soil fungi. Science.

Waksman, S. A., 1927. Principles of Soil Microbiology. Williams and Wilkins Co., Baltimore, Md.

\section{How to cite this article:}

Ch. Ramesh and Mallesh Baradwad. 2021. Isolation and Identification of Soil Mycoflora in Agricultural Fields of Hubli Taluk, Karnataka, India. Int.J.Curr.Microbiol.App.Sci. 10(08): 697-712. doi: https://doi.org/10.20546/ijcmas.2021.1008.079 